\title{
Decentralizing Rural Development Practice in Nigeria: The Challenges and Opportunities
}

\author{
Nseabasi S. Akpan \\ Department of Sociology and Anthropology, Faculty of Social Sciences, University of Uyo, Uyo, Akwa Ibom State, Nigeria
}

Email address:

akpan.nseabasi@ymail.com

To cite this article:

Nseabasi S. Akpan. Decentralizing Rural Development Practice in Nigeria: The Challenges and Opportunities. Humanities and Social Sciences. Vol. 3, No. 5, 2015, pp. 185-192. doi: 10.11648/j.hss.20150305.14

\begin{abstract}
The decentralization of economic and political powers has been an important tool for developing the rural and remote areas across the world. But how does decentralization work in some contexts and what are the challenges and opportunities? This paper discusses these issues in relation to Nigeria's rural development experiences and practices. Various Nigeria's rural development programmes have been reviewed to assess how their implementations have benefitted from decentralization practices. The results demonstrate that decentralization has not been strictly applied as a framework for the development of the rural areas. Colonial and post-colonial rural development plans have always been centrally directed. Even when constitutional reforms were effected to grant political, administrative, fiscal and financial autonomy to the rural areas through the local council authorities, actual implementation hardly reflect the ideals of decentralization. The paper argues that while the prospect of decentralization implies enormous opportunities for the development of the rural areas, such opportunity may hardly be realized due to a lack of local capacity to participate in local governance activities. Given this limitation, decentralization, in whatever form, will continue to be a tool to consolidate the State and elite powers.
\end{abstract}

Keywords: Local Government Autonomy, Local Capacity, Participation, Decentralization, Nigeria, Rural Development

\section{Introduction}

Decentralization involves the act of transferring 'decision-making authorities' from the centre to the lowest appropriate units. The transfer of decision-making authority may be from the capital city to the local government, district unit or village council, etc. The purpose of decentralizing powers and authorities is to serve many economic, social and political interests and encourage efficiency, equity, accountability and participation in decision-making process. The major form of decentralization located in the literature includes deconcentration, delegation and devolution. In deconcentration, representatives or employees of the centre transfer responsibilities and functions from the centre to the local levels for implementation. Devolution involves the transfer of the power to plan, budget, mobilize resources, and implement development programmes from the centre to the lowest appropriate units (see Prud'homme, 2003). Decentralization can also be seen from the point of view where power, authority and responsibility for political, fiscal and administrative systems are allocated between the centre and periphery.
Decentralization gives the local populace the power, voice and choice for better participation and as a means of influencing government to work according to community needs and demands. In this case, decentralization is an important channel in securing and guaranteeing improved quality of service delivered to local communities-this method of development has particularly been advocated for developing countries. Decentralization came into popularity in the 1980s and has since been embraced by the major international and regional organizations such as the World Bank and African Development Bank. While decentralization is often seen from a top-down perspective driven by the unitary or federal state in which the centre grants functions, authorities, and resources to sub-national and local levels, Brinkerhoff and Azfar (2006) argued that impulses for decentralization can also originate from these two local levels. Table 1 classifies different types of decentralization and identifies the features associated with each (see Brinkerhoff and Leighton, 2002).

Decentralization initiatives are geared toward developing the capacities of local communities and local self-government at the lowest appropriate units (mostly the village or clan units). This is to ensure that local development 
initiatives are made and responsibility for resource mobilization and allocation are taken at the local level (see Pandey and Misnikov, 2001). For decentralization to succeed, there should be self-governing grassroots institutions that serve to mobilize and enhance the role of the community in taking developmental initiatives that concern their livelihoods. How has the concept of decentralization advanced the development of rural areas? This question is addressed in the next section through a review of Nigeria's rural development practice and the extent to which it has benefitted from the principle of decentralization.

Table 1. Types and characteristics of decentralization practices.

\begin{tabular}{|c|c|c|c|}
\hline & Administrative & Financial/fiscal & Political \\
\hline Deconcentration & $\begin{array}{l}\text {-Local government follows central policies, plans } \\
\text { according to central norms. Form \& structure of } \\
\text { local government centrally determined. } \\
\text {-Local government staff are employees of central } \\
\text { ministries, accountable to center. } \\
\text {-Local government is service delivery arm of } \\
\text { center, little or no discretion in service choice or } \\
\text { mix, modes of provision. } \\
\text {-Local government provides information upwards } \\
\text { to center. }\end{array}$ & $\begin{array}{l}\text {-Local government is dependent on center for } \\
\text { funds; sectoral ministries and MOF provide } \\
\text { spending priorities \& budget envelope. } \\
\text {-Local government has no independent } \\
\text { revenue sources. } \\
\text {-Local government reports to center on } \\
\text { expenditure according to central formulas and } \\
\text { norms. } \\
\text {-Center conducts Local Government audits. }\end{array}$ & $\begin{array}{l}\text {-No elected local government; all } \\
\text { officials appointed by center \& } \\
\text { serve central interests. } \\
\text {-Civil society \& citizens rely on } \\
\text { remote \& weak links to central } \\
\text { government for exercising } \\
\text { accountability. } \\
\text {-Little political space for local } \\
\text { civil society, central elites control } \\
\text { politics. }\end{array}$ \\
\hline Delegation & $\begin{array}{l}\text {-Local government follows central policies \& } \\
\text { norms, has some discretion to tailor to local needs, } \\
\text { \& to modify form \& structure. } \\
\text {-Local government staff may be mix of central and } \\
\text { local government employees; local government } \\
\text { has authority on hiring \& placement; center } \\
\text { handles promotion \& firing. } \\
\text {-Local government provides service menu set by } \\
\text { center, some discretion in mix to fit local needs \& } \\
\text { in modes of provision. } \\
\text {-Local government provides most information } \\
\text { upwards to center \& selected information to local } \\
\text { officials, citizens. }\end{array}$ & $\begin{array}{l}\text {-Local government is dependent on center for } \\
\text { funds; LG has some discretion on spending } \\
\text { priorities within budget envelope. Block } \\
\text { grants \& conditional transfers from center } \\
\text { offer some autonomy. } \\
\text {-Local government has no independent } \\
\text { revenue sources. } \\
\text {-Local government reports to center and local } \\
\text { officials on expenditure according to central } \\
\text { formulas and norms. } \\
\text {-Center and LG conducts LG audits. }\end{array}$ & $\begin{array}{l}\text {-Local government may be a mix } \\
\text { of elected and centrally appointed } \\
\text { officials. } \\
\text {-Local officials often tied to } \\
\text { national party platforms, little } \\
\text { discretion. } \\
\text {-Some local accountability, but } \\
\text { strong central orientation. } \\
\text {-Some political space for local } \\
\text { civil society. }\end{array}$ \\
\hline Devolution & $\begin{array}{l}\text {-Local government is subject to national norms, } \\
\text { but sets local policies \& priorities, plans } \\
\text { autonomously in response to local preferences \& } \\
\text { needs. LG determines own form \& structure. } \\
\text {-Local government staffs are employees of LG, } \\
\text { which sets salaries, numbers, assignments, \& } \\
\text { handles hiring/firing. } \\
\text {-Local government determines service mix, modes } \\
\text { of provision, eligibility, \& allocation. } \\
\text {-Local government provides information to local } \\
\text { officials, citizens. }\end{array}$ & $\begin{array}{l}\text {-Local government sets spending priorities, } \\
\text { plans how to meet service delivery obligations } \\
\text { given resource availability. } \\
\text {-Local government has mix of own-source } \\
\text { revenues, revenue sharing, central transfers. } \\
\text {-Local government may have some authority } \\
\text { for debt financing, but is subject to a hard } \\
\text { budget constraint. } \\
\text {-Local government reports to local officials } \\
\text { and citizens on expenditure according to } \\
\text { central formulas and norms. } \\
\text {-Local government is responsible for audits, } \\
\text { reports results locally and to center. }\end{array}$ & $\begin{array}{l}\text {-Locally elected officials lead LG, } \\
\text { may or may not be linked to } \\
\text { national parties, platforms respond } \\
\text { to constituent demands and needs. } \\
\text {-Strong local accountability, LG } \\
\text { shapes budget priorities, } \\
\text { investments, service mix to fit } \\
\text { local preferences and needs. } \\
\text {-Broad political space for local } \\
\text { civil society. }\end{array}$ \\
\hline
\end{tabular}

\section{Decentralization and Rural Development: A Review of Nigeria's Development Plans}

Rural development practice in Nigeria often aims to, first, improve the quality of life of all members of the local community, and second, to involve all members of the community in the development process. Taking development to the rural areas with the aim of encouraging local participation is particularly possible within the framework of decentralized planning, but how much has it been practiced in the Nigerian national development plans?

Based on Conyers' (1986) 'top-down', 'bottom-up' and 'partnership' approaches ${ }^{1}$, rural development practice in Nigeria beginning from the colonial to post-independence has evolved at various levels as measured in the various rural development plans. The colonial rural development approach exhibited very high degree of centralized and top-down practice characterized by excessive economic

\footnotetext{
1 In a top-down approach to rural development, main activity of development is centrally initiated and managed by the government or authority while the community assumes a passive position. The bottom-up approach to rural development is actively initiated and managed by the intended beneficiary community while government and service providers merely play supportive role as facilitators and consultants. When the development attempt is combined or initiated by both the government and the community, it implies partnership between the people and government (see Finger, 1994; Nikkah and Redzuan, 2009).
} 
exploitation than the aim of improving the standard of living of the rural populace. Rural development in Nigeria under the British colonial system (1914-1960) did not carry clear specific plans. However, their interest in the rural areas was furthered by the need for material and human exploitation in the form of primary agricultural products and cheap labour to sustain their commercial interest and advance the economic and livelihood wellbeing of the colonial masters. Consequently, rural development was synonymous with highly centralized and well-organized system of disempowering and exploiting the rural populace and its resources.

Abdu and Marshall (1990) described such system as follows: 'under colonial rule, Nigeria was an outlier of Britain's economic space and the essentially exploitative relationship was based upon export commodity production...e.g., cocoa, palm oil produce, groundnuts and cotton. Agriculture was, therefore, the mainstay of the colonial economic system although the extraction of tin, using foreign capital, was of some importance' (p.313). Similarly, Iwuagwu (2006) saw such practice as being in consonance with the British colonial policy, which emphasized the search for less expensive human and material resources to develop and sustain the British colonial empire. This was absolutely a case of using the resources of the rural areas in developing the cities; just as available high tax revenue accruing from the rural communities did not match or correspond with the very low expenditures devoted for its development (Iwuagwu, 2006). The nature of social relations was unambiguously hierarchical with the colonial masters in London, their representatives in urban Nigeria, as well as the commoners settling in the rural areas. While the colonial masters and their representatives were interested in excessive dispossession and accumulation through directives, the commoners in the rural areas were responsible for local labour with low wages and without knowledge about how decisions affecting them were taken.

The 'parasitic' character of social relations in rural development practice did not end with the British rule; post-independence Nigeria inherited such mode of centralized rural development practice but to a certain extent. Frequent military intervention in Nigeria's post-independence governance, meant longer years of military rule (1966 to 1999 with a brief democratic interlude between 1979 and 1982) than civilian democracy (1999 to date). Under the military rule, various rural development plans came up as: a) the First National Development plan (1962-1968); b) the Second National Development plan (1970-1974); c) the Third National Development plan (1975-1980); d) the Fourth National Development plan (1980-1985); e) the post- Fourth National Development plan (1986-1998). Quite like the colonial arrangement, rural development practice under the post-independence military system was equally highly centralized and 'top-down' often conceived, legitimized and implemented by few individuals or groups who had access to public offices. Although the military used the State and local government systems to hand down development packages, the rural populace hardly got involved in the processes of development given that the local administrative leaders were military appointees who only acted for and on behalf of their masters. Consequently, every rural development programmes for Nigeria during this period carried uniform mandates and mostly was agriculturally based programmes.

The river basin development authority initiated and consolidated by the military and inherited by the civilian governments, still retain its uniform mandate and objectives of rural development in total disregard of the huge environmental, socio-economic and physical diversities of the various regions of Nigeria. Akpabio (2010), in this particular case of the river basin development authorities, had argued that most public policies and programmes in Nigeria hardly succeed because of utter disregard for local socio-ecological circumstances of operation. This argument applies to all other agricultural and rural development policies and programmes under the military regime except the short-lived second development plan (1970-1974). The uniqueness and participatory character of the second development plan could be appreciated against the backdrop of the circumstances of the post-civil war where the need for rehabilitation, and building a united and egalitarian society necessitated interest and subsequent engagement of relevant stakeholders. Such context of participatory governance and development soon could not be sustained given subsequent military intervention. In this case, all other subsequent development plans claimed participation, though falsely, at inter-governmental levels, which in reality amounted to mere directives and communication of what to implement at the state and local government levels.

The emergence of democratic governance beginning from 1999 was to offer the best opportunity for decentralized rural development at every level. For one, the constitution of Nigeria guarantees, in principle, some levels of autonomy to state and local authorities. Second, the power of democratic election and political informational debates offer remarkable political incentives for decentralized and participatory development at every levels of governance. However, these standards have not yet been internalized in the Nigerian political space. Every known rural development programme beginning from 1999 hardly reflect the true perspectives of the diverse stakeholders and voices. Nigeria's democratic governance still remains relatively young. Most rural development efforts revolve around the National Economic Empowerment and Development Strategy (NEEDS) that are all duplicated at State levels as State Economic Empowerment and Development Strategy (SEEDS) and Local Economic Empowerment and Development Strategy (LEEDS). The NEEDS was formally launched in May 2004, and was designed to serve as a homegrown economic empowerment and development programme. Although the NEEDS and its 
local wings emphasized stakeholder participation, the entire planning process is in total negation of the principle of decentralization. The formulation of terms of reference, appointment and composition of facilitators as well as problem identification are often pre-determined at the top (relevant central agencies). Local stakeholders are only co-opted as members of project implementation committee whose role nominally revolves around site identification for project implementation. The entire process that even results in the composition of the 'so-called' stakeholder implementation committee members is often fraught with excessive politicization as opportunity to reward and patronize the local members of the ruling political party. Decentralization in this context merely works to satisfy sectional and elitist interests. True decentralization would aim to give voice to local populace to define their problem and proffer solutions in a way that will improve their wellbeing.

The 'decentralization' perspectives of every rural development programme under the current democratic arrangements often assumes rhetorical public statements while actual practice, at best, is narrowed to administrative decentralization. This is when States and local government areas duplicate such federal initiatives at their respective domain. While Nigeria assumes a constitutional federal structure, real autonomy is still lacking in practice as the States and local authorities still depend on the federal government for funding. States and local level authorities hardly take independent rural developmental initiatives as they practically depend on the federal authorities. In most cases, rural development programmes and policies are still driven by individuals and select few in public offices, as was common practice during the military dictatorship. Just as in the military era, the survival of every rural development programme is often closely tied to regime longevity and individual influence in a given regime and department of government, rather than the relevant institutional structures. Taking example of the Vision 2010 of the Sani Abacha regime, Aluko (2006) observed that in spite of the best ideas and intentions encapsulated in the reform agenda, the subsequent regime led by Olusegun Obasanjo terminated the plan because of sheer hatred for Abacha. He went on to observe that Obasanjo's tenure elongation programme was explicitly premised on guaranteeing the survival of his Vision 2020 plan. In the case of NEEDS, Osagie (2007: 29) particularly observed a lack of institutional coordination and absence of effective leadership as most important problems that limit efforts at guaranteeing sustainable and long-term rural development programme.

In summary, it is argued that rural development practice in Nigeria over the years has been a one-way practice still centrally packaged by public officials and development agents, and handed down to the people who become passive recipients of such public development benefits. Such top-down rural development perspectives are still very much common even in the current democratic experiment.
This is explained with reference to a lack of basic capability on the part of the citizens to participate and negotiate in the processes that are intended for their own development benefits.

\section{Decentralization and Nigeria's Rural Development: Opportunities and Challenges}

The option of decentralizing rural development in Nigeria gains momentum following the fundamental criticisms of centralized and top-down planning in a highly multi-complex society as Nigeria, which tends to give less emphasis on the grass root and local actors. Policy makers at the center are often seen as important actors while other actors are seen as not very relevant and may even constitute impediments. In most contexts centralized decision-making process constitute difficulties of use due to rather a multitude of governmental directives and actors, none of them pre-eminent (Sabatier, 1986). This is one of the most common experiences in some policy issues that touch on several sectors of Nigeria's economy. The agricultural sector, for instance, crosscuts several sectors including water and land resources, food security, infrastructural supplies and research, etc. Consequently, most central government policies on agricultural development are implemented in several federal government ministries in an uncoordinated manner. Several local actors are most likely to be ignored during policy implementation, and this does not encourage development that affect the real needs of the local actors.

Decentralized rural development can also be known as development from below or grassroots development. It is a rural development idea that is aimed at supporting alternative development approach for poor and developing countries. The failure and inherent problems often characterizing the centralized or top-down approach to rural development necessitated interest in the decentralized alternative. Based on Friedmann (1988 as cited in Sanyal, un-dated), the idea of decentralization as a development approach is built around the intellectual argument that broad-based political and economic development would not be achieved by centralized, top-down initiatives, rather what is required depends on the bottom by the people themselves who are capable of generating income and employment and for political mobilization.

Successful decentralization of development practice depends enormously on the mechanism of small-scale development initiatives and projects which could serve the purpose of income generation and employment opportunity as well as fostering small local solidarity groups. Such platforms offer remarkable channel for collective consciousness and mobilization among the poor especially on how they could get out of poverty condition. Such local mobilization create opportunity for empowering the poor as well as providing spaces for face-to-face interaction and sharing of experience as well as generating some form of 
social network (Stearns 1985, Everett and Savara 1987).

Decentralization as a tool for rural development in Nigeria has not recorded any remarkable impact in practice. The greater part of efforts to develop the rural areas was packaged around agricultural development. This dominated the colonial and post-colonial periods up to the late 1980s when some elements of broad conceptualization of rural development were witnessed through investment in physical and social infrastructures. Emphasis on agriculture alone reflects the single handedness or unilateral approach to rural development where government alone conceptualizes the problem of the rural areas and consequently decides on what it perceives as best for every rural areas and its people. This equally gives some insights into the exploitative nature of most public rural development programmes as agricultural development is often targeted, not in the true sense of developing the rural areas and its people but as a means of guaranteeing stable food supply for the leaders and urban elites. Given that Nigeria's economy is agrarian-based, the rural areas were perceived to be important productive centers to service the foreign exchange earnings of the country. As rural people's livelihoods do not entirely depend on agriculture, its overemphasis functions much to the detriment and neglect of many other productive sectors of the rural economy which could place some areas at a relative comparative advantage. Thus, other key sectors of rural development including rural small scale craft industries and human capital development through investments in wide range of social opportunities including education, healthcare etc. were ignored. This is an indication that the people's voices were hardly engaged in discussing the best developmental options for them.

Long years of military rule have been seen to be one factor contributing to the absence of institutionalized decentralization in rural development. The military were not able to create enabling institutional environment for participatory governance given that power revolved around individuals and groups within the military hierarchy. Every rural development package including DFFRI, Operation Feed the Nation (OFN) and Green Revolution, etc. had no record of evidence to the fact that the people were consulted. The development plans were framed at the seat of power by one or few individuals and handed down for implementation without recognition of the variation in local environmental and socio-economic circumstances of the people. When Nigeria started experiencing democratic governance, the needed institutional foundation for democratic decentralization was already not nurtured. This has affected the functioning of Nigeria's current democratic experiment as individuals and leaders still cultivate enormous power and influence over the machinery of government, to the extent that corruption, nepotism and poor leadership have combined not only to corrupt public development processes, but also serve to inhibit the proper functioning of public policies and plans that are meant for rural development.

Citizenship participation and input in any policy formulation and programme implementation processes is very crucial since the outcome of such arrangements is bound up with popular views and inputs and is useful in empowering local level development actors and intended beneficiaries as well as strengthening the sustainability of development project. Current challenge to effort at decentralization in Nigeria border on: a) citizens capacity to participate in development intended for their benefit and; b) transparency guarantees in the intended processes of participation. Given that over $70 \%$ of Nigerians are classified as poor (IFAD, 2011), it means the basic human and socio-economic capabilities that would guarantee substantive participation in development practice is absent (see Sen, 1999). While some public rural development programmes seem to support decentralization, actual practices are often narrowed to unilateral top-down package as those in the policy and administrative leadership still dominate every rural development spaces. Communities are often handed water facility where either there are many natural sources of supplies or the cost of access marginalizes the greatest number of the people. Given a lack of basic citizen capabilities and capacity to participate in public rural development programmes, the transparency in the processes of delivering such public development benefits becomes increasingly diminished. Policy officials and implementers often manipulate development programmes to the dictates of ethnicity, clan affiliation, financial gratification and undue favoritism, among several other corrupt practices.

Several criticisms have been labeled against decentralization as a rural development approach (see Sabatier, 1986 for details). First advocates for this approach are known to fall into the problem of having to give overemphasis on the ability of the local actors to frustrate the center. More specifically, the focus on local actors' goals and strategies may underestimate the Center's indirect influence over those goals and strategies through its ability to affect the institutional structure in which individuals operate (Sabatier, 1986 cited Kiser and Ostrom, 1982). Second relates to its failure to start from an explicit theory of the factors affecting the subject of interest. Sabastier (1986) supported this point by arguing that 'because it relies very heavily on the perception and activities of participants, it is their prisonerand therefore is unlikely to analyze the factors indirectly affecting their behavior or even the factors directly affecting such behaviors which the participants do not recognize' (pp.35).

Sabastier (1986) argued that the centralization and decentralization schools have been motivated by somewhat different concerns and thus have developed different approaches. The centralization school has been preoccupied with (a) the effectiveness of specific governmental programmes and b) the ability of elected officials to guide and constrain the behaviors of civil servants and target groups. The author observed that addressing such concerns requires a careful analysis of the formally approved objectives of elected officials, an examination of relevant performance indicators, and analysis of the factors affecting such performance. The decentralization school, on the other 
hand is far less pre-occupied with the extent to which a formally enacted policy decision is carried out and much more concerned with a policy problem. Sabastier (1986) argued that they are not primarily concerned with the implementation of a policy per se but rather with understanding actor interaction in a specific sector.

\section{Discussions and Concluding Remarks}

Nigeria's federal structure comprises of three tiers of government namely, the Federal (central), the State and the Local governments. This structure serves to respond to the complex developmental needs of a multi-ethnic and multi-cultural nature of the country. The local tier (Local government) was designated as the grass root spatial units with the responsibility of achieving the development of the rural areas. Currently, Nigeria has 774 local government areas distributed across the 36 States of the Federation and the Federal Capital Territory (FCT) at Abuja. The 1976 reform defined the local government as: 'Government at local level exercised through representative councils established by law to exercise specific powers within defined areas'. In 1999, the powers of the local authorities were further streamlined. Section 7 provides for a democratically elected local government councils, while Section 8 empowers States to ensure their existence under a law, which provides for the establishment, structure, composition, finance and functions of such councils.

The local government system came to symbolize the practice of decentralization to encourage development at the lowest level or tier of the country. Section 7 (1) of the 1999 Constitution outlined the financial and funding arrangements for local governments through the following provision (Okafor 2010):

a. The national assembly shall make provision for statutory allocation of public revenue to local government councils in the federation; and

b. The House of Assembly of a State shall make provisions for statutory allocation of public revenue to local government councils within the State.

Additionally, section 162 further states that:

i. Any amount standing to the credit of the federation account shall be distributed among the Federal and State governments and the local councils in each State on such terms and in such manner as may be prescribed by the National Assembly;

ii. The amount standing to the credit of local government councils in the Federation account shall also be allocated to the State for the benefit of their local councils in such terms and in such manner as may be prescribed by the National Assembly;

iii. Each State shall pay to local government councils in its area of jurisdiction such proportion of its total revenue on such terms and in such manner as may be prescribed by the National Assembly

In principle, the local government was meant to operate as a third tier of government within its area of jurisdiction, with full fiscal, legislative, political and administrative autonomy. This was expected to free the third tier of some extraneous influences, while at the same time guaranteeing full power to initiate policies and implement projects and programmes for the development of their respective rural areas. The 1999 Constitution also created a special account called State Joint Local Government Account (SJLGA) maintained by each State government for the purposes of receiving 'paid allocations to the local government councils of the State from the Federation Account and from the government of the State' (Section 162: 6). Section 162 (8) further states that: 'the amount standing to the credit of local government councils of a State shall be distributed among the local government councils of that State on such terms and in such manner as may be prescribed by the House of Assembly of the State'.

All these incremental reforms were directed at securing a decentralized and autonomous local authorities to be directly involved in the delivery of local services and other rural development activities. Though the State-Local government relation was meant to strengthen and encourage accountability, it has become the biggest source for undermining the autonomy of the local councils. State governments have had overbearing control and influence over their respective Local authorities. In the first instance, Nigeria's third tier of government practically lacks the necessary political autonomy. The 1999 Constitution had envisaged a third tier of government that would be democratically elected by the people. This is hardly the case, as most local councils have become avenues for political patronage in their respective States. Caretaker committees at the instance of their respective State governments occasionally administer almost all the local government councils. Democratic elections hardly represent the will of the electorates as the State government in power, in collusion with the State legislature, use such opportunity as a means to cultivate and install political loyalists. In essence, the third tier of government lacks the necessary fiscal, financial, legislative, political and administrative autonomy. They only exist to pay salaries of staff and implement the directives of their respective State governments. The general public perception of Nigeria's local government councils has been very negative. Their existence and impacts are hardly felt by the rural areas they are supposed to represent. There is high level of corruption and a lack of political and financial accountability. Isa (2015) has argued that the existence of local councils only serve to advance the practices of corruption often witnessed through several cases of financial fraud, contract inflation, 'ghost worker' syndrome and a total lack of accountability and transparency in administration.

In conclusion, the dream of using the local authorities as agents of rural development has not been successful. Although the local councils are guaranteed autonomy at every facet of political, fiscal, administrative and financial levels by the Constitution, actual practice is that of councils operating at the mercy of their respective State governments. In another dimension, the greatest threat to achieving full decentralization and autonomy for the local council is the clear absence of citizenship capacity of participation in local 
governance and electoral politics. The rural populace is generally the poorest segments of the Nigerian population. Majority does not have basic education or the necessary exposure to participate in local governance and to enforce necessary transparency and accountability on their representatives as well as influencing the local electoral politics. One of the cardinal principles for attaining effective decentralization in local governance is the presence of robust and active citizenship participation, without which the process for decentralizing local power remains a one way affair in favor of the local elites and the State governments. For a proper and successful decentralization practice, the paper recommends that massive public investments and spending should be directed at improving social opportunities such as education, healthcare and economic empowerment. Such investments in social and economic opportunities will contribute in improving the basic capabilities of the rural populace and will contribute in guaranteeing effective participation in any development process. Finally the State Local Joint Government Joint Account system should be abolished, while some structures and measures to enforce financial and fiscal discipline and accountability are put in place, to guarantee full financial autonomy for the local authorities.

\section{References}

[1] Abass, I. M. (1993). The challenge of rural development strategies in a deregulated economy. Paper prepared for a national seminar on rural development-doing more less developing rural resources in a deregulated economy-organized by New Nigerian Newspapers Limited in collaboration with Arthur Green consultants held at Shiroro Hotel Minna, Niger State from 10th-12th February.

[2] Abdu, M. S. and R. Marshall (1990). Agriculture and development policy: a critical review of Nigerian experience in the period upto 1985. Journal of Rural Studies, 6(3): 311-323.

[3] Akpabio, E. M. (2010). Integrated Water Resources Management in Nigeria: Local factors and institutional challenges. Lap Lambert Academic Publishing, Germany.

[4] Aluko, S. (2006). Abacha's vision 2010 Blueprint reviewed. \#airaland Forum. Tuesday May 09, 2006.

[5] Brinkerhoff, Derick and Charlotte Leighton (2002). "Decentralization and Health System Reform: Issue in Brief." Washington, DC: U.S. Agency for International Development. Partners for Health Reform plus Project. Insights for Implementers. No. 1, September.

[6] Brinkerhoff, D. W., with O. Azfar (2006). Decentralization and community empowerment: does community empowerment deepen democracy and improve service delivery? Paper prepared for: U. S. Agency for International Development office of democracy and governance. RTI International, Washington DC.

[7] Conyers, D. (1986). Decentralization and development: a framework for analysis. Community development journal 21 (2).
[8] Everett, J. and M. Savara (1987). Institutional credit as a strategy toward self-reliance for petty commodity producers in India. In A. M. Singh and A. Kellas- Vitanen (eds). Invisible hands: women in home-based productions. Pp. 207-228. New Delhi: Sage.

[9] FGN (1981). Fourth National Development Plan (1981-85). Federal Republic of Nigeria, Lagos.

[10] Finger, M. (1994). NGOs and transformation: beyond social movement theory. Environmental NGOs in world politics: linking the local and the global. T. Princen and M. Finger. London, Routledge: 48-66.

[11] Friedmann, J. (1988). The barrio economy and collective self-empowerment in Latin America. In: J. Friedmann (ed). Life space and economic space: essays in third world planning. New Brunswick: Transaction Books. Pp. 108-146.

[12] IFAD (2011). Rural Poverty in Nigeria. http://www.ruralpovertyportal.org/web/guest/country/home/ta gs/nigeria. International Fund for Agricultural Development.

[13] Isa MK (2015). Nigerian local government system and governance: lessons, prospects and challenges for post 2015 development goals. Presented at the International Research Society for Public Management Conference, University of Birmingham, UK $30^{\text {th }}$ March to April $2^{\text {nd }}$.

[14] Iwuagwu, O. (2006). Rural development in eastern Nigeria: an assessment of colonial and post-colonial development plans in the former Owerri Province, 1946-1976. Lagos Historical Review, 6: 118-132.

[15] Johnson, Ronald (1995). "Decentralization Strategy Design: Complementary Perspectives on a Common Theme." Washington, DC: US Agency for International Development, Implementing Policy Change Project, August.

[16] Kiser, L. and Ostrom, E. (1982). The three worlds of action. In E. Ostrom, B. Hills (eds): strategies of political inquiry. Sage, pp.179-22.

[17] Nikkhah, H. A. and Ma'rof Redzuan (2009). Participation as a medium of empowerment in community development. European Journal of Social Sciences. Vol. 11, No. 1: 170-176.

[18] Okafor J. (2010). Local government financial autonomy in Nigeria: the State Joint Local Government Account. Commonwealth Journal of Local Governance. Issue 6: 127-131.

[19] Osagie, E. (2007). The New Nigerian Economy: from poverty to prosperity. Benin City: AFBSN Publications.

[20] Panda, B. (2007). "Top Down or Bottom Up? A Study of Grassroots NGOs' Approach." Journal of Health Management 9(257).

[21] Prud' home, R. (2003). Fiscal decentralization in Africa: a framework for considering reform. Publication Administration and Development, Vol. 23, pp.17-27.

[22] Sabastier, P. A. (1986). Top-down and bottom-up approaches to implementation research: a critical analysis and suggested synthesis. Journal of Public Policy 6 (01): 21-48).

[23] Sanyal, B. (un-dated). The myth of development from below. Pp. $1-20$

[24] Sen, A. (1999). Development as freedom. Oxford University Press. Oxford. 
[25] Stearns, K. E. (1985). Assisting informal sector microenterprises in developing countries. Ithaca: Cornell International Agricultural Economics Study.
[26] World Bank (2004). World Development Report 2004: making services work for the poor. Washington, DC: World Bank. 